\title{
Optimization of Extrusion Variables for the Development of RTE Snacks by Incorporation of Pearl Millet Starch
}

\author{
Isha Kaushik* and R.B. Grewal \\ Centre of Food Science and Technology, CCS HAU, Hisar, Haryana, India-125004 \\ *Corresponding author
}

\begin{tabular}{|c|c|}
\hline & A B S T R A C T \\
\hline & A study was conducted to process pearl millet and develops ready to eat healthy \\
\hline & $\begin{array}{l}\text { extruded snacks. For that purpose, designed experiments were conducted to } \\
\text { prepare pearl millet-starch based RTE extrudates by using three independent }\end{array}$ \\
\hline Extrusion, & variables (feed composition, moisture content and cutter speed) and nine \\
\hline $\begin{array}{l}\text { Optimization, } \\
\text { Pearl Millet }\end{array}$ & dependent variables (bulk density, expansion ratio, hardness, texture and overall \\
\hline Starch, & acceptability) using response surface methodology (RSM). Quadratic model was \\
\hline RSM. & $\begin{array}{l}\text { developed by using central composite design (CCD) of response surface } \\
\text { methodology (RSM) to optimize the extrusion variables. During the experiment }\end{array}$ \\
\hline Article Info & feed composition, moisture content and cutter speed varies from $68-100 \%, 13.3-$ \\
\hline $\begin{array}{l}\text { Accepted: } \\
\text { 19 June } 2017\end{array}$ & $\begin{array}{l}21.7 \% \text { and } 7-10 \mathrm{rpm} \text {, respectively with constant screw speed }(350 \mathrm{rpm}) \text {, barrel } \\
\text { temperature }\left(121^{\circ} \mathrm{C}\right) \text { and feed rate }(25 \mathrm{~kg} / \mathrm{hr}) \text {. Variables optimized for preparation }\end{array}$ \\
\hline $\begin{array}{l}\text { Available Online: } \\
10 \text { July } 2017\end{array}$ & of acceptable pearl millet RTE snacks with $84.5 \%$ desirability included $85.09 \%$ \\
\hline & $\begin{array}{l}\text { pearl millet flour, } 14.91 \% \text { pearl millet starch at } 17.80 \% \text { moisture content and 8rpm } \\
\text { cutter speed. }\end{array}$ \\
\hline
\end{tabular}

\section{Introduction}

\section{Practical applications}

Pearl millet falls in underutilized crop albeit it's good nutritional quality. Pearl millet is also rich in starch content and its starch can be used as a replacer of other traditional starches such as cereal and tuber starches. So, use of pearl millet flour and incorporation of its starch can open the new opportunities for food product developers/researchers to made nutritive and expanded ready-to-eat products etc.

In recent years consumers are in search for food that not only adequately meet the nutritional requirements but also have characteristics which can ensure good health. The increasing awareness towards healthy food opened wide area for nutritious coarse cereals viz., sorghum and pearl millet. The pearl millet (Pennisetum typhoides) is the 6th most important and drought tolerant food crop of semi arid regions of South Asia and Africa due to its sustainability at adverse agroclimatic conditions (Sihag et al., 2015). India is the largest producer of the pearl millet in the world and its cultivation is next to rice, maize and wheat. In India, pearl millet is mainly consumed in the form of chapatti and considered as poor man's food (Siroha et al., 
2015 and FAO, 2016). Pearl millet commonly known as bajra and termed as "nutricereal" due to presence of complex carbohydrates, protein of good biological activity, lipid, vitamins and minerals. It also contains high proportion of dietary fibers, and other phytochemicals with nutraceutical properties (Sihag et al., 2015 and Yadav et al., 2014). However, it has remained as the food for poor and traditional consumers because of limited availability of ready-to-use or ready-to-eat pearl millet based products. Pearl millet could seek great potential as an ingredient in RTE extruded snacks because of its lower cost (Balasubramanian et al., 2012), but have less expansion and low sensory score of colour of extrudates prepared using pearl millet (Kattak, 2014).

RTE snack foods now are getting an interest of consumers due to its convenience, attractive appearance, taste and texture (Euromonitor, 2001). Cereal based RTE snacks can be sweet or savory, light or substantial, and many even are endowed with attributes such as 'healthy' or 'just for fun'. Nowadays, nutritional features of food are becoming relevant determinants of consumption with impunity by all groups of people around the world due to increasing health problem such as obesity and other related diseases (Balasubramanian et al., 2012).

This makes to move on other technologies and ingredients to produce good quality and heathy snacks for the consumer. Extrusion cooking is one of the efficient technologies to produce variety of different shape and size food products such as snack-foods, babyfoods, breakfast cereals, pasta, noodle and cereals based blends (Fellow, 2003; Semaska et al., 2010). It is a high-temperature, shorttime process that plasticizes and cooks moistened, flour/grits in different forms by a combination of moisture, pressure, temperature and mechanical shear. The losses of nutrients are lower than other thermal processing methods and also reduce the antinutritional factors (phytate, tannins and trypsin inhibitor) (Fellow, 2003 and Ficarella et al., 2004). Pearl millet based extruded snacks blended with other cereals and legumes (Balasubranaian et al., 2012) and whey protein concentrate (Yadav et al., 2014) has been reported.

But pearl millet based extrudates had dense and hard texture, low expansion and low sensory score (Yadav et al., 2014) as compared to extruded snacks prepared from rice (Charunuch et al., 2011) and corn (Semasaka et al., 2010). Quality of the extruded product/snacks depends on the various controls of the extrusion process and proper manipulation of any, some or all the processing conditions through adoption of well-defined experimental design influence ultimate extrudate quality and functionality (Nor et al., 2013). One of key factor is type of feed, use of starchy cereal, incorporation of starch used in extrusion results in expansion, low bulk density and crispy texture of extruded snacks (Chinnaswamy, 1993). For optimizing product/processes one of the statistical and mathematical techniques is RSM. Response surface methodology was developed by Box and collaborators in the $50 \mathrm{~s}$. This term was originated from the graphical perspective generated after fitness of the mathematical model. It reduces the number of experimental runs in development of different type of products involving complex process variables. It can be well applied when a response or a set of responses of interest are influenced by several variables. The objective is to simultaneously optimize the levels of these variables to attain the best system performance (Bezerra et al., 2008; Kumar and Devi 2011). The present study was conducted to optimize process parameters to develop good quality pearl millet based extruded RTE snacks. 


\section{Materials and Methods}

Pearl millet grains (var. HHB-256), was procured from the Department of Genetics and Plant Breeding, CCSHAU, Hisar, Haryana, India. Pearl millet grains were cleaned and dried. Dried millets were grounded to flour by lab scale flour milling machine. Pearl millet starch was extracted from HHB-256 pearl millet variety by wet milling method using $0.1 \% \mathrm{Na}_{2} \mathrm{~S}_{2} \mathrm{O}_{5}$.

\section{Experimental design}

Response surface methodology which involves design of experiments, selection of levels of variables in experimental runs, fitting mathematical models and finally selecting variables levels by optimizing the response (Khuri and Cornell, 1996) was employed in the study. A Central Composite Rotatable Design (CCRD) was used to design the experiments comprising of three independent processing parameters using Design expert 10.0.3.1 software. Twenty sets of experiments were performed (Table 1) taking into account 3 factors viz., feed composition (68-100\%), moisture content $(13.3-21.7 \%)$ and cutter speed $(7-10 \mathrm{rpm})$. There were six experiments at centre point to calculate the repeatability of the method.

\section{Extrusion processing}

For the preparation of extruded snacks, pearl millet flour and pearl millet starch were mixed in different proportions. To the mixture, different level of water was mixed according to the RSM runs. The mixture was kept for $30 \mathrm{~min}$ at ambient temperature and remixed before extrusion. The extrudates were prepared using BTPL lab model twin screw extruder at screw speed $(350 \mathrm{rpm})$, feed rate $(25 \mathrm{~kg} / \mathrm{hr})$ and $3 \mathrm{~mm}$ die opening. Extrudate rods were cut through a variable cutter speed (7-10 rpm), dried at $40 \pm 2{ }^{\circ} \mathrm{C}$ for $30 \mathrm{~min}$ in hot air oven and stored in air tight containers at ambient conditions $\left(20-30{ }^{0} \mathrm{C}\right)$ for further analysis.

\section{Quality evaluation of RTE extruded snacks}

Pearl milled based extruded snacks were analysed for physical attributes (bulk density, expansion ratio, hardness) and sensory characteristics by using standard methods in triplicates.

\section{Bulk density}

The bulk density (BD) was determined by the procedure (Pan et al., 1998). 100 pieces of extrudates (about $2 \mathrm{~cm}$ in length) were placed in a $500 \mathrm{ml}$ graduated cylinder. The bottom of the cylinder was tapped gently on a laboratory bench until there was no further reduction in sample volume. The volume and weight was noted and bulk density was calculated by dividing weight of sample to volume.

\section{Expansion ratio}

The expansion ratio was determined by the method Harper (1981). The cross-sectional diameters of extrudates were determined using vernier caliper. The expansion ratio was calculated as the ratio of diameter of extrudates to that of die. Expansion ratio is $\mathrm{De} / \mathrm{Dd}$; where, De is cross sectional diameter of extrudates and Dd is diameter of die.

\section{Hardness (N)}

Hardness of ready-to-eat extruded snacks was assessed using TA XT-plus Texture analyzer in triplicates using $35 \mathrm{~mm}$ cylinder probe $(\mathrm{CP} / 36)$ with $5 \mathrm{Kg}$ load cell. The force required to crush the extruded snacks was considered as hardness of snacks.

\section{Sensory evaluation of RTE snacks}

Extrudates were evaluated for color, appearance, flavor, taste and texture using 9- 
point Hedonic scale by a panel of semitrained judges drawn from Centre of Food Science and Technology at CCSHAU, Hisar, Haryana, India. Sensory evaluation was done at room temperature $\left(25{ }^{0} \mathrm{C}\right.$ ) (Amerine et al., 1965). Average of the scores for all the sensory characteristics was expressed as overall-acceptability score.

Statistical Analysis
The experiments were performed and responses were fitted in the design. After each individual experiment, responses were analyzed to assess the effect of independent variables on them. The first order or second order polynomial equation (Eq. 1) examines the statistical significance of the model and the following form was fitted to the responses:

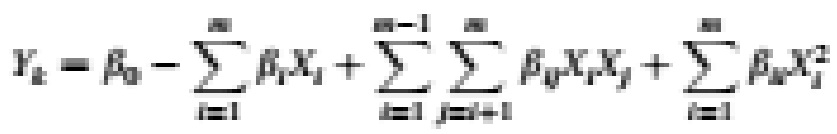

(Equation 1)

Where, Y response variable, $\beta$ o, $\beta \mathrm{i}, \beta \mathrm{ii}$ and $\beta \mathrm{ij}$ regression coefficient, $\mathrm{Xi}$ and $\mathrm{Xj}$ coded independent variables. Numerical optimization technique of the Design-Expert software (10.3.01) was used for simultaneous optimization of the multiple responses.

\section{Optimization and validation}

The present study was carried out for the optimization of extrusion variables and effect of these variables on the physical and organoleptic quality of RTE snacks of pearl millet such as bulk density, expansion ratio, texture, color, appearance, flavor, taste, texture and OAA. The desired goals for each factor and responses were chosen (Table 2). Responses obtained after each trials were analyzed to visualize the validity of the selected run.

\section{Results and Discussion}

The results obtained from the present investigation with regard to influence of three independent variables viz., feed composition, moisture content and cutter speed, on nine product response variables viz., bulk density, expansion ratio, hardness, color, appearance, flavor, taste, texture and overall acceptability for standardization of acceptable RTE snacks have been described under different sections.

\section{Bulk density}

Bulk density is one of the important expansion indices. It measures puffing of expanded products, and has negative correlation to expansion (Charunch et al., 2011). Bulk density of pearl millet extrudates was ranged from 0.071-0.165 g/cc (Table 1). Highest bulk density of pearl millet extrudates was observed for extrudate prepared with PMF:PMS (68:32) at $17.5 \%$ moisture content with 9 rpm cutter speed whereas lowest bulk density was noticed for extrudates prepared with PMF:PMS (85:15) at similar moisture content and cutter speed. It was observed that bulk density of extrudates was significantly affected by linear term A (feed composition) and quadratic term AB (feed composition*moisture content) (Fig. 1). The magnitude of regression coefficients of feed composition and moisture content process variables showed a negative effect at the linear term $(\mathrm{A}=-0.015, \mathrm{~B}=-3.025 \mathrm{E}-003)$ while cutter speed $(\mathrm{C}=2.040 \mathrm{E}-003)$ had positive effect (Equation 2). The quadratic 
equation obtained by RSM from regression analysis for bulk density in terms of coded level of variables could be presented as follow:

Bulk density $=+0.076-0.015 * \mathrm{~A}-3.025 \mathrm{E}-$ $003 * \mathrm{~B}+2.040 \mathrm{E}-003 * \mathrm{C}+0.019 * \mathrm{AB}-2.500 \mathrm{E}-$ $003 * \mathrm{AC}-5.000 \mathrm{E}-004 * \mathrm{BC}+0.020 * \mathrm{~A}^{2}+3.546 \mathrm{E}-$ $003 * \mathrm{~B}^{2}+1.030 \mathrm{E}-005 * \mathrm{C}^{2}$

\section{(Equation 2)}

Where $\mathrm{A}=$ feed composition, $\mathrm{B}=$ moisture content, $\mathrm{C}=$ cutter speed

The significance of coefficient of fitted quadratic model was evaluated by using Fvalue and $\mathrm{P}$-value. The analysis of variance (ANOVA) for bulk density of quadratic model eq. (2) is given in table 2. Regression model fitted to experimental result of bulk density showed that F-value was 8.71 and $\mathrm{P}$ value was 0.0011 which implies that model is significant. Whereas lack of fit value was significant which implies model was lack to fit. The value of coefficient of determination $\left(\mathrm{R}^{2}\right)$ was 0.89 which means data can be consider for further optimization.

RSM 3D graph (Fig. 1) indicates that bulk density of pearl millet based extrudates decreased with addition of pearl millet starch up to $15 \%$ and further addition of starch increased the bulk density of extrudates. This might be due to inappropriate moisture content for starch gelatinization which leads to dense interior of expanded products and resulted in increased bulk density. Low moisture (15-30\%) extrusion tends to result in processes with greater generation of mechanical energy and products with lower density, while high moisture (50-70\%) extrusion results in products with higher density (Guy, 2001). Fayose (2013) also observed blocking of rotation of screws of extruder at low moisture content and reported a range of feed moisture (30-50\%) suitable for maize starch based extrusion. Thus, physical characteristics of extrudates depends upon moisture content and amylose content of starch (Chinnaswamy and Hanna, 1987), and rheological properties of extruded starchy melts which depends upon the ratio between vapour pressure and melt viscosity, and found good correlation at moisture content $<25 \%$ (Kokini et al., 1990). Similarly to present study, Kattak (2014) also reported that bulk density of extrudates prepared from whole pearl millet flour is high whereas bulk density of pearl millet based extrudates decreased with addition of corn flour or starch in pearl millet flour.

\section{Expansion ratio}

Expansion ratio is an important physical attribute of the extruded snacks and it is an indicator of puffing quality of extruded snacks. The quality of expanded snacks is judged mainly from their crispness, which is directly related to their expansion (Chinnaswamy and Hanna, 1987). Starch is the main component of cereal which plays major role in expansion process. Expansion occurring in food material depends on the pressure differential between the die and atmosphere. It has been predicted that value of expansion ratio increased with increase moisture content and feed composition i.e., as amount of starch increased expansion ratio increased (Cinnaswamy and Hanna, 1990).

The result of experimental design to expansion ratio of RTE pearl millet snacks under different process variables are depicted in table 1. Expansion ratio of pearl millet extrudates varied from 2.57 to 3.48 (Table 1). The magnitude of regression coefficients of feed composition, moisture content and cutter speed process variables showed a positive effect at the linear term $(\mathrm{A}=3.24, \mathrm{~B}=0.06$ and $\mathrm{C}=0.12$ ) (Eq. 3). The quadratic equation obtained by RSM from regression analysis for 
expansion ratio in terms of coded level of variables could be presented as follow:

Expansion ratio

$=$ $+3.24+0.061 * \mathrm{~A}+0.12 * \mathrm{~B}+0.049 * \mathrm{C}-$ $0.19 * \mathrm{AB}+0.011 * \mathrm{AC}-0.024 * \mathrm{BC}-0.19 * \mathrm{~A}^{2}-$ $0.045 * \mathrm{~B}^{2}+0.079 * \mathrm{C}^{2}$

\section{(Equation 3)}

Results indicate that expansion ratio was increased with increase in moisture content while further addition of starch, decrease the expansion ratio of pearl millet based extrudates (Fig. 1). However, expansion ratio was less affected by cutter speed as shown in 3D graph (Fig. 1). Hence, AB interaction had significant effect on expansion ratio. Sun and Muthukumarappan (2002) extruded soy and corn flour and reported that expansion ratio increased with increase in feed moisture from 13 to $18 \%$. Kattak (2014) also studied that expansion of maize and pearl millet based extrudates varies with the feed composition and moisture content that maximum expansion at 14\% moisture level with (40:60) corn and pearl millet flour whereas with feed composition (20:80) corn and pearl millet flour at $12 \%$ moisture level. Similar trend was observed in this study. The results of present study are also in agreement to studies of Cinnaswamy and Hanna (1988) and Fayose (2013), those who scrutinized that expansion of extrudates not only depends upon barrel temperature and screw speed, but also other factors such as type of source of starch, nature of starch, quantity of starch and moisture content of feed also influence the physical quality of extrudates.

The significance of coefficient of fitted quadratic model was evaluated by using Fvalue and $p$-value. The analysis of variance (ANOVA) for expansion of quadratic model eq. (3) is given in table 2. Regression model fitted to experimental result of expansion ratio showed the F-value was 9.45 and $\mathrm{P}$ value is 0.0008 which implies that model is significant. The value of lack of fit was 0.40 which implies the model was good to fit. The value of coefficient of determination $\left(\mathrm{R}^{2}\right)$ was 0.89. Considering all the above criteria, the model can be fitted for further analysis.

\section{Hardness}

The hardness of expanded extrudates is the peak force required for a probe to compress the extrudates. Higher value of peak force indicates higher hardness of the sample. Hardness of pearl millet extrudate varied from 35.6 to $52.1 \mathrm{~N}$ (Table 1). It had been noticed from RSM 3D graph (Fig. 2) and table 1, maximum hardness was observed with feed composition (100:00) of pearl millet flour and starch. Addition of starch in pearl millet flour $(85: 15)$, decreased hardness to $35.6 \mathrm{~N}$ of extrudates while further addition of starch in pearl millet flour $(75: 25)$ at $15 \%$ moisture content, resulted in increased hardness of pearl millet extrudates (Fig. 2). This might be due to lack of appropriate shear viscosity which unable to promote bubble growth and thereby making the product quite dense (Kristiawan et al., 2016). Similar results were noticed by Yadav et al., (2014) who reported that cell strength influenced by starch gelatinization and protein content. Hence, moisture content had significant effect on starch viscosity and physical attribute of extrudates (Gat and Ananthanarayan, 2015). The results of present study of hardness of pearl millet are in confirmation to Kattak (2014), who also reported that feed composition and moisture content had significant effect on hardness and concluded that hardness decreased with addition of corn flour in pearl millet flour with addition of more moisture content. However, there is still a dearth of information and knowledge on how the starch incorporation in feed affect the rheological properties of the extrudate both pre and post die (Fig. 3). 
The result of experimental design to hardness of RTE pearl millet extrudate snacks under different process variables are depicted in table 1. The magnitude of regression coefficients of moisture content and cutter speed process variables showed a positive effect at the linear term $(B=1.25$ and $C=$ 0.25) whereas feed composition had negative effect $(A=-1.29)$ and a positive effect was shown by all interaction terms in equation 4 . The quadratic equation obtained by RSM from regression analysis for hardness in terms of coded level of variables could be presented as follow:

Hardness $\quad=\quad+38.07-$ $1.29 * \mathrm{~A}+1.25 * \mathrm{~B}+0.25 * \mathrm{C}+2.66 * \mathrm{AB}+0.40 * \mathrm{AC}$ $+0.99 * \mathrm{BC}+4.80 * \mathrm{~A}^{2}+2.92 * \mathrm{~B}^{2}+0.21 * \mathrm{C}^{2}$

(Equation 4)

The significance of coefficient of fitted quadratic model was evaluated by using Fvalue and $p$-value. The analysis of variance (ANOVA) for hardness of quadratic model eq. (4) is given in table 2 . Regression model fitted to experimental result of expansion ratio showed the F-value was 13.10 and $\mathrm{P}$ value is 0.0002 which implies that model is significant. The value of lack of fit was 3.65 which imply the model was good to fit. The value of coefficient of determination $\left(\mathrm{R}^{2}\right)$ was 0.92 .

\section{Overall-acceptability (OAA)}

Sensory quality is a combination of different senses of perception coming into play in choosing and eating a food product. Various sensory parameters, viz., appearance, taste, texture, color, etc., result in the OAA of the food product (Baniwal and Hathan, 2015). The overall sensory acceptability score varied from 6.2 to 8.5 for the extrudate samples of pearl millet (Table 1). It was observed that experiment no 8 showing high OAA score at $0.066 \mathrm{~g} / \mathrm{cc}$ bulk density, $3.48 \%$ expansion ratio and $38.29 \mathrm{~N}$ hardness at $85 \%$ feed composition, $17.5 \%$ moisture content and 7 rpm cutter speed. From 3D RSM graph (Fig. 2 ), it was observed that moisture content and feed composition had significant effect on OAA whereas no significant effect was noticed for cutter speed on OAA of pearl millet based extrudates. It was predicted that OAA of expanded product was high at moderate level of starch and further addition of starch decreased the OAA score by panelists.

Similar results for pearl millet extrudates was documented by Kattak (2014) that OAA of pearl millet extrudates increased with addition of pearl millet starch in cereal mix either improved or did not change sensory characteristics of value added RTE snacks.

The result of experimental design to texture of RTE pearl millet extrudate snacks under different process variables are depicted in table 1. OAA of pearl millet extrudate varied from 6.2 to 8.5. The magnitude of regression coefficients of moisture content and cutter speed process variables showed a negative effect at the linear term $(B=-0.25$ and $C=-$ 0.28 ) whereas feed composition had positive effect $(\mathrm{A}=0.067)$ (Equ. 4). The quadratic equation obtained by RSM from regression analysis for OAA in terms of coded level of variables could be presented as follow:

$$
\begin{aligned}
& \mathrm{OAA}=+8.11+0.12 * \mathrm{~A}-0.31 * \mathrm{~B}-0.32 * \mathrm{C}- \\
& 0.95 * \mathrm{AB}+0.25 * \mathrm{AC}-0.25 * \mathrm{BC}-0.84 * \mathrm{~A}^{2}- \\
& 0.21 * \mathrm{~B}^{2}+7.093 \mathrm{E}-003 * \mathrm{C}^{2}
\end{aligned}
$$

(Equation 4)

The significance of coefficient of fitted quadratic model was evaluated by using Fvalue and $p$-value. The analysis of variance (ANOVA) for texture of quadratic model eq. (10) is given in table 2. Regression model fitted to experimental result of expansion ratio showed the F-value was 10.37 and $\mathrm{P}$ value is 
0.0005 which implies that model is significant. The value of lack of fit was 4.45 which imply the model was good to fit. The value of coefficient of determination $\left(\mathrm{R}^{2}\right)$ was 0.90

The adjusted $\mathrm{R}^{2}(0.82)$ and predicted $\mathrm{R}^{2}$ (0.37). The adequate precision value was 9.35 which were more than 4 which indicate desirability and adequacy of the signal. Considering all the above criteria, the model can be fitted for further analysis.

\section{Optimization and validation}

Optimization of extrusion process variables for production of RTE pearl millet snacks was carried out to obtain desired criteria for each response. The desired goals for each independent variable and response were chosen as presented in table 3. The independent variables were kept in range, while the responses were maximized, minimized or not selected (bulk density, color, appearance and flavor) based on the desirable characteristics of the RTE pearl millet snacks.

Fig.1 Response surface graph for combined effect of feed moisture, feed composition and cutter speed on Bulk density and Expansion ratio of extrudates

Bulk density
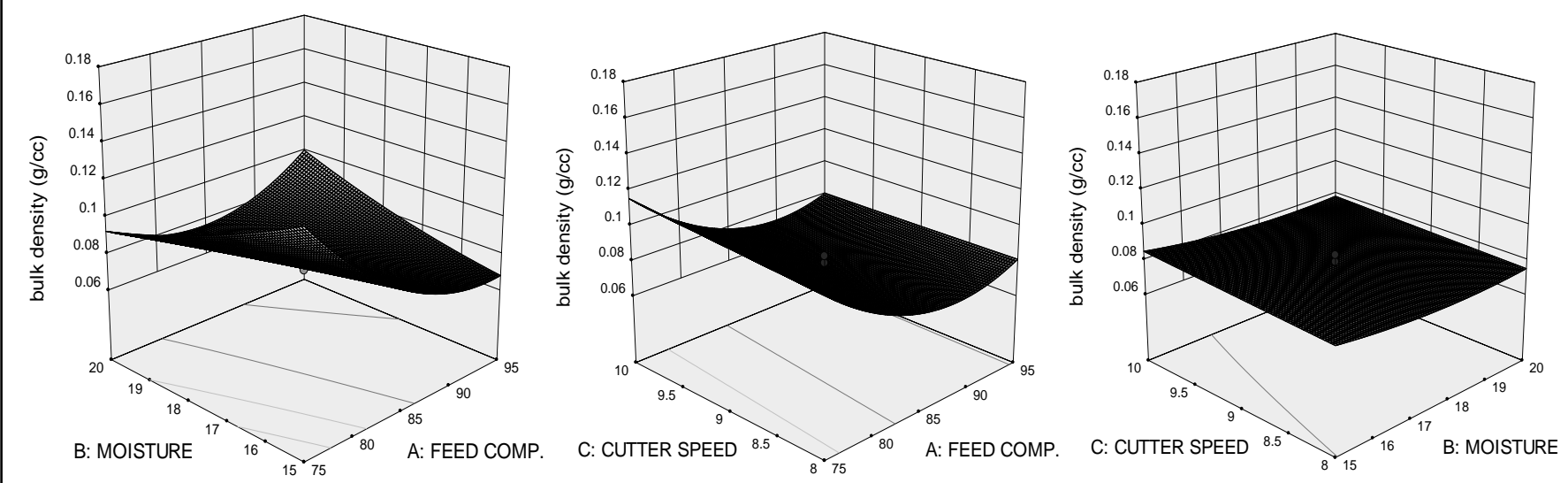

Fig.2 Response surface graph for combined effect of feed moisture, feed composition and cutter speed on expansion ratio of extrudates

\section{Expansion ratio}
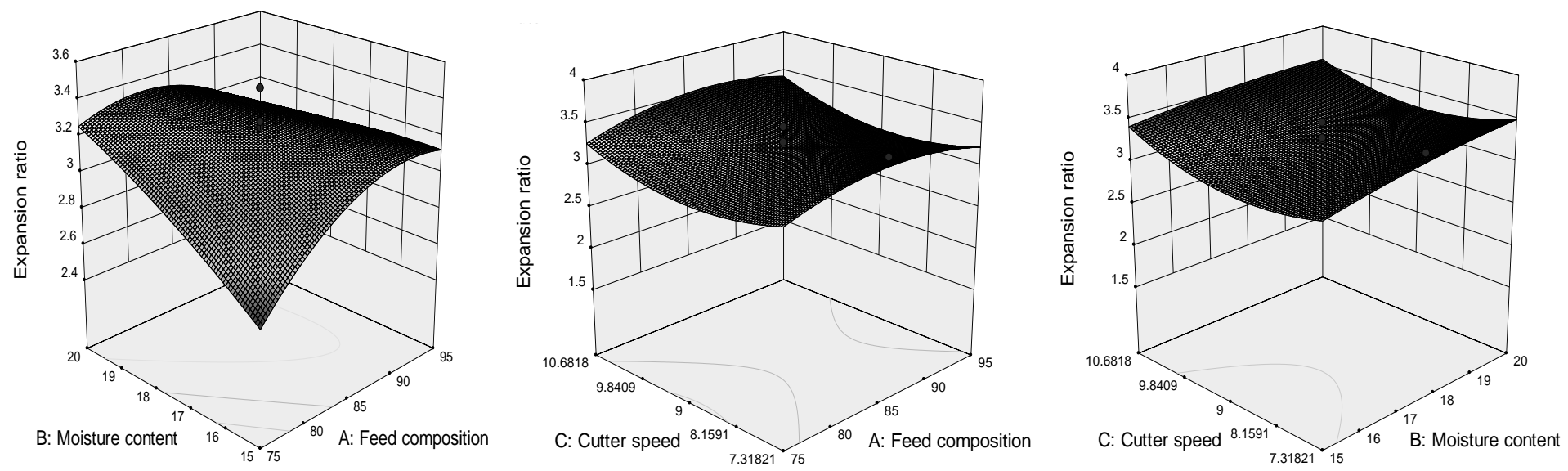
Fig.3 Response surface graph for combined effect of feed moisture, feed composition and cutter speed on hardness of extrudates

\section{Hardness}
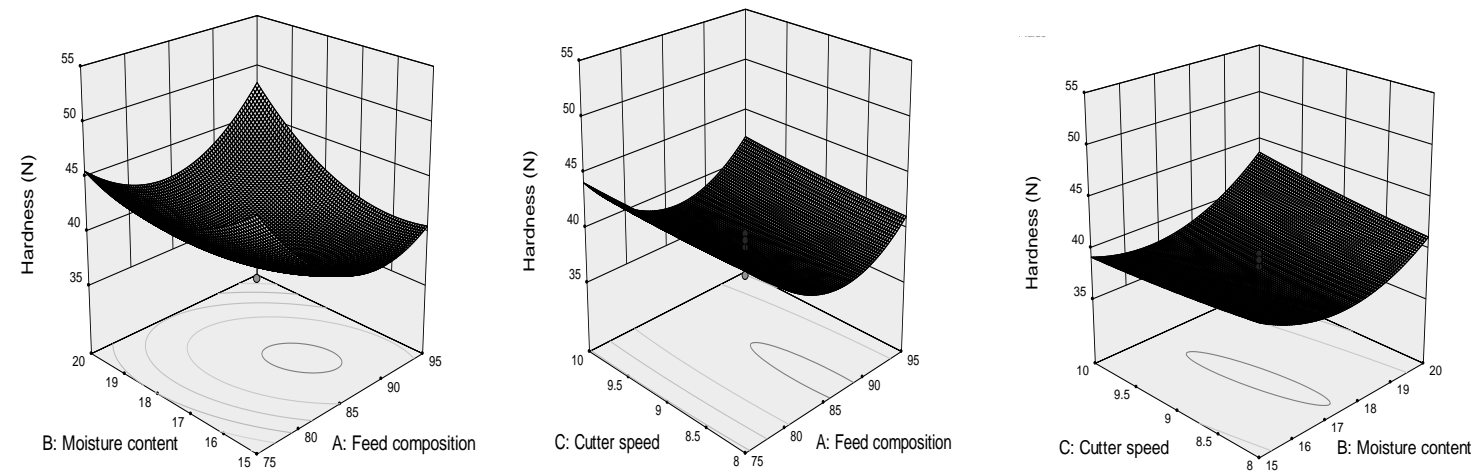

Fig.4 Response surface graph for combined effect of feed moisture, feed composition and cutter speed on OAA of extrudates

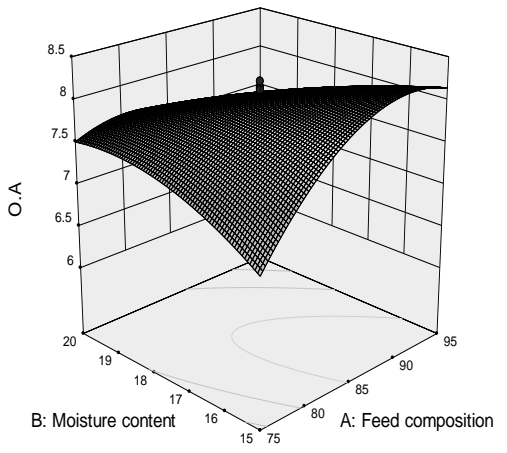

Out of 10 solutions, solution no. 1 had superior OAA (8.9) with desirability (0.845) was selected. This optimized solution was further validated by analyzing the responses for the sample extruded at the above mentioned conditions and the values are very much close to predicted ones and thus reconfirm the validity of this model (Table 3 ) (Fig. 4).

In conclusion, the study indicates that starch has significant effect on physical and sensory attributes of pearl millet based extrudates. There is increase in expansion ratio and sensory score with addition of starch content up to a desired level with adequate level of moisture content. No effect of cutter speed is determined due to lack of response related to size. Among the twenty combinations of

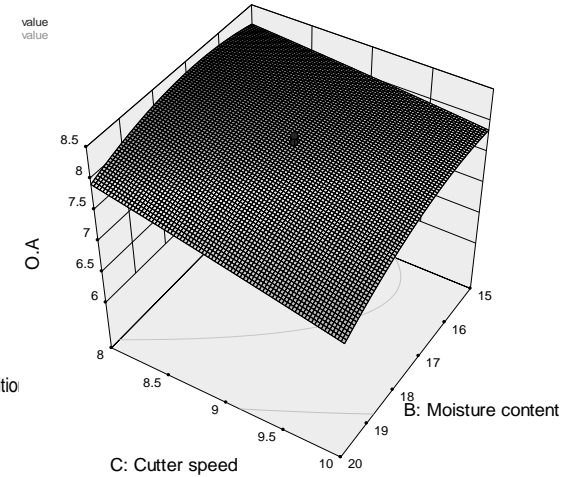

RSM, extrudates with $84.5 \%$ desirability include $85.09 \%$ pearl millet flour, $14.91 \%$ pearl millet starch at $17.80 \%$ moisture content and $8 \mathrm{rpm}$ cutter speed was selected. The optimized extruded snacks had bulk density $(0.074 \mathrm{~g} / \mathrm{cc})$, expansion ratio (3.28), hardness (38.1 N) and OAA (8.3). Acceptable RTE pearl millet snacks can be prepared by incorporating $15 \%$ pearl millet starch in formulation of pearl millet flour with $17.8 \%$ moisture content extruded at $25 \mathrm{~kg} / \mathrm{hr}$ feed rate and $121{ }^{0} \mathrm{C}$ temperature with $8 \mathrm{rpm}$ cutter speed. Mathematical models from regression analysis can be used to interpret the relationship between the effect of extrusion variables on physical and sensory attributes of extruded snacks. Good agreement between the values predicted and those determined experimentally confirm the adequacy of these 
models. Such information could help food processors predict the optimum extrusion conditions for preparation of RTE snacks from pearl millet starch. Pearl millet starch can be utilized in the formulation for development of RTE extruded snacks with improved physical and sensory attributes. Thus, processing of pearl millet to starch can be alternative source of corn starch for starch industries and development of pearl millet based RTE snacks.

\section{References}

Amerine, M.A., Pongborn, R.H. and Roescler, E.B. 1965. Principles of sensory evaluation of food. Academic, New York, pp 338-339.

Balasubramanian, S., Singh, K., Patil, R. and Onkar, K. 2012. Quality evaluation of millet-soy blended extrudates formulated through linear programming. J. Food Sci. Technol., 49(4): 450-458.

Baniwal, P. and Hathan, B. 2015. Process parameter optimization for the development of ready-to-eat instant sand pear candy using response surface methodology. J. Food Processing and Preservation, 39(6): 3098-3109.

Bezerra, M., Santelli, R., Oliveira, E., Villar, L., and Escaleira, L. 2008. Response surface methodology (RSM. as a tool for optimization in analytical chemistry. Talanta, 76(5): 965-977.

Charunuch, C., Limsangouan, N., Prasert, W., and Butsuwan, P. 2011. Optimization of extrusion conditions for functional ready-to-eat breakfast cereal. Food Sci. Technol. Res., 17(5): 415-422.

Chinnaswamy, R. and Hanna, M. 1987. Nozzle dimension effects on the expansion of extrusion cooked corn starch. J. Food Sci., 52(6): 1746-1747.

Chinnaswamy R. 1993. Basis of cereal starch expansion. Carbohydrate polymer, 25: 157-167.
Chinnaswamy, R. and Hanna, M. 1990. Relationship between viscosity and expansion properties of variously extrusion-cooked corn grain components. Food Hydrocolloids, 3(6): 423-434.

Euromonitor International. 2001. Report: savory snacks market in the US. Euromonitor International, Chicago.

FAO (Food and Agricultural Organization). 2016. Economic and Social Department: The Statistical Division. Available online: http://www.fao.org/faostat/en/\#data/QC

Fayose, F. 2013. Expansion characteristics of selected starchy crops during extrusion. The West Indian J. Engi., 35(2): 58-64.

Fellows, P.J. 2003. Food Processing Technology: Principles and Practice, Woodhead Publishers Limited, England.

Ficarella, A., Milanese, M., and Laforgia, D. 2004. Numerical study of the extrusion process in cereals production: part I. Fluid-dynamic analysis of extruder system, 73: 103-111.

Gat, Y. and Ananthanarayan, L. 2014. Effect of extrusion process parameters and pregelatinized rice flour on physicochemical properties of ready-toeat expanded snacks. J. Food Sci. Technol., 52(5): 2634-2645.

Guy, R. 2001. Extrusion cooking: technologies and applications, Woodhead Publishing, Cambridge, United Kingdom.

Harper, J.M. 1981. Extrusion of foods. Baca Raton, CRC, press. pp. 212.

Karmakar, R., Ban, D.K., and Ghosh, U. 2014. Comparative study of native and modified starches isolated from conventional and nonconventional sources. Int. Food Res. J., 21(2): 597602.

Kattak, A. 2014. Evaluation, processing and utilization of pearl millet for preparation 
of value added RTE snacks. Ph.D. Thesis, CCS Haryana Agricultural University, Hisar, India.

Khuri, A.I. and Cornell, J.A. 1996. Response Surfaces, Second Edition. Dekker, New York, pp 510.

Kokini JL, Lai L, Chedid LL (1992). Effect of starch structure on starch rheological properties. Food Technol., 124-139.

Kristiawan, M., Chaunier, L., Della Valle, G., Ndiaye, A. and Vergnes, B. 2016. Modeling of starchy melts expansion by extrusion. Trends in Food Sci. Technol., 48, 13-26.

Kumar, S.P. and Devi, P. 2011. Optimization of some process variables in mass transfer kinetics of osmotic dehydration of pineapple slices. Int. Food Res. J., 18, 221-238.

Nor, N., Carr, A., Hardacre, A., and Brennan, C. 2013. The Development of expanded snack product made from pumpkin flour-corn grits: effect of extrusion conditions and formulations on physical characteristics and microstructure. Foods, 2(2): 160-169.

Pan, Z., Zhang, S. and Jane, J. 1998. Effects of extrusion variables and chemicals on the properties of starch based binders and processing conditions. Cereal Chem., 75, 541-546.

Semasaka, C., Kong, X. and Hua, Y. 2010.
Optimization of extrusion on blend flour composed of corn, millet and soybean. Pak. J. Nutrition, 9(3): 291297.

Sihag, M., Sharma, V., Goyal, A., Arora, S. and Singh, A. 2015. Effect of domestic processing treatments on iron, $\beta$ carotene, phytic acid and polyphenols of pearl millet. Cogent Food and Agri., 1(1): $1-12$.

Siroha, A., Sandhu, K. and Kaur, M. 2016. Physicochemical, functional and antioxidant properties of flour from pearl millet varieties grown in India. Food Measure, 10(2): 311-318.

Suknark, K., Phillips, R. and Chinnan, M. 1997. Physical properties of directly expanded extrudates formulated from partially defatted peanut flour and different types of starch. Food Res. Int., 30(8): 575-583.

Sun, Y. and Muthukumarappan, K. 2002. Changes in functionality of soy-based extrudates during single-screw extrusion processing. Int. J. Food Properties, 5(2): 379-389.

Yadav, D., Anand, T., Navnidhi, and Singh, A. 2014. Co-extrusion of pearl milletwhey protein concentrate for expanded snacks. Int. J. Food Sci. Technol., 49(3): 840-846.

\section{How to cite this article:}

Isha Kaushik and Grewal, R.B. 2017. Optimization of Extrusion Variables for the Development of RTE Snacks by Incorporation of Pearl Millet Starch. Int.J.Curr.Microbiol.App.Sci. 6(7): 1607-1617. doi: https://doi.org/10.20546/ijcmas.2017.607.194 
Table.1 Experimental runs and actual values of factors used in central composite rotatable design

\begin{tabular}{|c|c|c|c|c|c|c|c|c|}
\hline & \multicolumn{3}{|c}{ Variables } & \multicolumn{5}{c|}{ Responses } \\
\hline Run & $\begin{array}{c}\text { Feed composition } \\
(\%) \\
\text { PMF:PMS }\end{array}$ & $\begin{array}{c}\text { Moisture } \\
\text { content } \\
(\%)\end{array}$ & $\begin{array}{c}\text { Cutter } \\
\text { speed } \\
(\mathbf{r p m})\end{array}$ & $\begin{array}{c}\text { Bulk } \\
\text { density } \\
(\mathbf{g} / \mathbf{c c})\end{array}$ & $\begin{array}{c}\text { Expansion } \\
\text { Ratio }\end{array}$ & $\begin{array}{c}\text { Hardness } \\
(\mathbf{N})\end{array}$ & Texture & OAA \\
\hline 1 & $85: 15$ & 17.5 & 10 & 0.079 & 3.47 & 38.43 & 7.6 & 7.6 \\
\hline 2 & $95: 05$ & 20 & 8 & 0.104 & 3.01 & 44.98 & 6.0 & 6.9 \\
\hline 3 & $85: 15$ & 21.7 & 9 & 0.094 & 3.27 & 48.45 & 6.8 & 6.5 \\
\hline 4 & $75: 25$ & 15 & 8 & 0.14 & 2.57 & 50.61 & 5.8 & 6.9 \\
\hline 5 & $85: 15$ & 17.5 & 9 & 0.083 & 3.46 & 38.22 & 8.2 & 8.1 \\
\hline 6 & $75: 25$ & 20 & 8 & 0.08 & 3.3 & 46.89 & 8.6 & 8.2 \\
\hline 7 & $85: 15$ & 17.5 & 9 & 0.079 & 3.28 & 35.6 & 8.4 & 8.2 \\
\hline 8 & $85: 15$ & 17.5 & 7 & 0.066 & 3.48 & 38.29 & 9.0 & 8.5 \\
\hline 9 & $85: 15$ & 17.5 & 9 & 0.075 & 3.25 & 37.5 & 8.3 & 8.1 \\
\hline 10 & $85: 15$ & 17.5 & 9 & 0.071 & 3.2 & 38.9 & 8.0 & 8.0 \\
\hline 11 & $95: 05$ & 15 & 8 & 0.082 & 3.04 & 40.78 & 8.4 & 8.0 \\
\hline 12 & $95: 05$ & 15 & 10 & 0.082 & 3.29 & 39.04 & 8.2 & 8.0 \\
\hline 13 & $85: 15$ & 13.3 & 9 & 0.071 & 2.98 & 43.58 & 8.6 & 8.2 \\
\hline 14 & $85: 15$ & 17.5 & 9 & 0.074 & 3.00 & 39.5 & 8.3 & 8.2 \\
\hline 15 & $75: 25$ & 20 & 10 & 0.088 & 3.41 & 47.5 & 6.4 & 6.9 \\
\hline 16 & $95: 05$ & 20 & 10 & 0.097 & 3.15 & 49.89 & 6.2 & 6.6 \\
\hline 17 & $100: 00$ & 17.5 & 9 & 0.093 & 2.82 & 52.14 & 5.8 & 6.4 \\
\hline 18 & $68: 32$ & 17.5 & 9 & 0.165 & 2.59 & 50.54 & 6.0 & 6.7 \\
\hline 19 & $85: 15$ & 17.5 & 9 & 0.076 & 3.23 & 38.8 & 7.4 & 7.7 \\
\hline 20 & $75: 25$ & 15 & 10 & 0.145 & 2.76 & 49.98 & 6.0 & 6.2 \\
\hline
\end{tabular}

*PMF:PMS=Pearl Millet Flour: Pearl Millet Starch 
Table.2 Statistical results of response surface models for RTE pearl millet snacks

\begin{tabular}{|c|c|c|c|c|c|c|c|c|c|c|}
\hline \multirow{2}{*}{$\begin{array}{l}\text { Statistical Parameters } \\
\text { Coefficient }\end{array}$} & \multicolumn{2}{|c|}{ Bulk density (g/cc) } & \multicolumn{2}{|c|}{ Expansion ratio } & \multicolumn{2}{|c|}{ Hardness (N) } & \multicolumn{2}{|c|}{ Texture } & \multicolumn{2}{|c|}{ OAA } \\
\hline & $\begin{array}{c}\text { F- } \\
\text { value }\end{array}$ & P value & $\begin{array}{c}\text { F- } \\
\text { value }\end{array}$ & P value & $\begin{array}{c}\text { F- } \\
\text { value }\end{array}$ & P value & $\begin{array}{c}\text { F- } \\
\text { value }\end{array}$ & $P$ value & $\begin{array}{c}\text { F- } \\
\text { value }\end{array}$ & $P$ value \\
\hline Model & 8.71 & 0.0011 & 9.45 & 0.0008 & 13.10 & 0.0002 & 8.45 & 0.0013 & 10.37 & 0.0005 \\
\hline A-Feed composition & 20.47 & 0.0011 & 3.36 & 0.0968 & 5.02 & 0.0489 & 0.71 & 0.4189 & 0.58 & 0.4654 \\
\hline B-Moisture content & 0.80 & 0.3923 & 13.82 & 0.0040 & 4.71 & 0.0552 & 4.59 & 0.0578 & 7.91 & 0.0184 \\
\hline C-Cutter speed & 0.36 & 0.5600 & 2.17 & 0.1712 & 0.19 & 0.6755 & 4.87 & 0.0518 & 10.04 & 0.0100 \\
\hline$A B$ & 18.95 & 0.0014 & 19.67 & 0.0013 & 12.50 & 0.0054 & 25.33 & 0.0005 & 24.26 & 0.0006 \\
\hline$A C$ & 0.32 & 0.5843 & 0.066 & 0.8020 & 0.28 & 0.6072 & 1.75 & 0.2149 & 3.85 & 0.0783 \\
\hline$B C$ & 0.013 & 0.9122 & 0.30 & 0.5986 & 1.72 & 0.2186 & 1.75 & 0.2149 & 1.00 & 0.3398 \\
\hline$A^{2}$ & 36.81 & 0.0001 & 35.42 & 0.0001 & 73.51 & $<0.0001$ & 35.79 & 0.0001 & 40.03 & $<0.0001$ \\
\hline$B^{2}$ & 1.16 & 0.3071 & 1.93 & 0.1949 & 27.15 & 0.0004 & 2.13 & 0.1756 & 8.37 & 0.0160 \\
\hline$C^{2}$ & $9.770 E-006$ & 0.9976 & 5.82 & 0.0365 & 0.14 & 0.7155 & $2.543 E-003$ & 0.9608 & 0.027 & 0.8731 \\
\hline Lack of Fit** & & 0.0038 & & 0.8335 & & 0.0909 & & 0.1142 & & 0.0636 \\
\hline R-squared & & 0.8868 & & 0.8948 & & 0.9218 & & 0.8838 & & 0.9032 \\
\hline Adjusted & & 0.7850 & & 0.8002 & & 0.8514 & & 0.7793 & & 0.8161 \\
\hline Predicted & & 0.1783 & & 0.6647 & & 0.4997 & & 0.2259 & & 0.3731 \\
\hline Adequate precision & & 10.212 & & 10.941 & & 10.476 & & 8.320 & & 9.345 \\
\hline
\end{tabular}

**Lack of fit (p-value>0.05) non-significant. Hence, models are fit and good for evaluation.

Table.3 Constraints of the numerical optimization of the responses for RTE pearl millet snacks

\begin{tabular}{|c|c|c|c|c|c|c|c|c|}
\hline Variable & Goal & Lower limit & Upper limit & Lower weight & Upper weight & Importance & $\begin{array}{c}\text { Predicted } \\
\text { value }\end{array}$ & $\begin{array}{c}\text { Experimental } \\
\text { value }\end{array}$ \\
\hline $\begin{array}{c}\text { A:Feed } \\
\text { composition }\end{array}$ & is in range & 75 & 95 & 1 & 1 & 3 & 85.09 & - \\
\hline $\begin{array}{c}\text { B:Moisture } \\
\text { content }\end{array}$ & is in range & 15 & 20 & 1 & 1 & 3 & 17.80 & - \\
\hline C:Cutter speed & is in range & 8 & 10 & 1 & 1 & 3 & 8 & - \\
\hline Bulk density & none & 0.066 & 0.165 & 1 & 1 & 3 & 0.074 & 0.061 \\
\hline Expansion ratio & maximize & 2.57 & 3.48 & 1 & 1 & 3 & 3.284 & 3.162 \\
\hline Hardness & minimize & 35.6 & 52.14 & 1 & 1 & 3 & 38.091 & 35.991 \\
\hline OAA & maximize & 6.2 & 8.48 & 1 & 1 & 3 & 8.298 & 7.977 \\
\hline
\end{tabular}

